\title{
New faunistic records of the jumping and crab spiders of Karakoram, Pakistan (Aranei: Philodromidae, Salticidae and Thomisidae)
}

\author{
Новые фаунистические находки пауков скакунчиков и \\ бокоходов в Каракоруме, Пакистан \\ (Aranei: Philodromidae, Salticidae $и$ Thomisidae)
}

\author{
Dmitri V. Logunov ${ }^{1}$, Francesco Ballarin ${ }^{2}$ \& Yuri M. Marusik ${ }^{3}$ \\ А.В. Аогунов ${ }^{1}$, Ф. Баммарин ${ }^{2}$, Ю.М. Марусик ${ }^{3}$

\footnotetext{
The Manchester Museum, The University of Manchester, Oxford Road, Manchester M13 9PL, UK. E-mail: dmitri.v.logunov@manchester.ac.uk

${ }^{1}$ Манчестерский Музей, Университет Манчестера, Оксфорд Роуд, Манчестер M13 9PL, Великобритания.

${ }_{2}^{2}$ Museo Civico di Storia Naturale di Verona, Lungadige Porta Vittoria, 9 - 37129, Verona, Italy. Email: ballarin.francesco@gmail.com

${ }^{2}$ Государственный Музей Естественной Истории, 9 - 37129, Верона, Италия.

${ }_{3}^{3}$ Institute for Biological Problems of the North FEB RAS, Portovaya Str. 18, Magadan 68500, Russia. E-mail: yurmar@mail.ru

${ }^{3}$ Институт биологических проблем Севера ДВО РАН, ул. Портовая 18, Магадан 685000, Россия.
}

KEY WORDS: Pakistan, Karakoram, spiders, Aranei, new findings.

КЛЮЧЕВЫЕ СЛОВА: Пакистан, Каракорум, пауки, Aranei, новые находки.

ABSTRACT. The present work provides new faunistic data on eight spider species of the families Philodromidae, Salticidae and Thomisidae from Karakoram (Pakistan). Five species are illustrated and the females of two species (Philodromus timidus and Thanatus fornicatus) are redescribed. The distribution of all the recorded species is discussed. T. fornicatus is reported for the faunas of Kazakhstan and Uzbekistan for the first time.

РЕЗЮМЕ. В настоящей работе обсуждаются новые фаунистические находки восьми видов пауков из семейств Philodromidae, Salticidae и Thomisidae из Каракорума (Пакистан). Пять видов проиллюстрированы, и самки двух из них (Philodromus timidus и Thanatus fornicatus) переописаны. Обсуждается распространение всех отмеченных видов. Вид T. fornicatus отмечается впервые для фаун Казахстана и Узбекистана.

\section{Introduction}

The spider fauna of Karakoram (northern Pakistan) remains poorly known. Despite the interesting, high mountainous landscape of this territory, only about 130 spider species have been recorded from there to date [e.g. Caporiacco, 1934; Kok et al., 2004, 2005; Ovtchinnikov, 2006; Ovtchinnikov et al., 2008; Ovtchinnikov \& Inayatullah, 2005; Marusik \& Ballarin, 2011a,b]. Unfortunately, some of the earlier records from Kara- koram [particularly those of Kok et al., 2004, 2005], as well as many other spider records from the rest of Pakistan [e.g. Mushtaq et al., 1995; Butt \& Beg, 2000; Ghafoor \& Alvi, 2008; and others], require confirmation upon reference to the pertinent material, as sometimes even the generic assignment of some species seems incorrect. Thus, the lack of reliable information on the Pakistan spiders poses difficulties in the analysis of the distribution of many Central Asian species.

New spider material from northern Pakistan (Karakoram) was recently collected during the surveys undertaken by the Museo Civico di Storia Naturale of Verona (Italy). This paper presents new faunistic records of the jumping (Salticidae) and crab (Philodromidae and Thomisidae) spiders collected from Karakoram during these surveys. The new faunistic records allow us to clarify the distribution of the eight reported species in Central Asia.

\section{Material and methods}

Photographs of the copulatory organs and general appearance were made using an Olympus SZX16 stereomicroscope with an Olympus Camera E-520 digital camera. To take photographs different dishes with paraffin on the bottom were used. Different sized holes were made on the paraffin to retain specimens in the correct position. Pictures were generated using "CombineZM" montage software. The format of descriptions and abbreviations follows Logunov [1996] and 

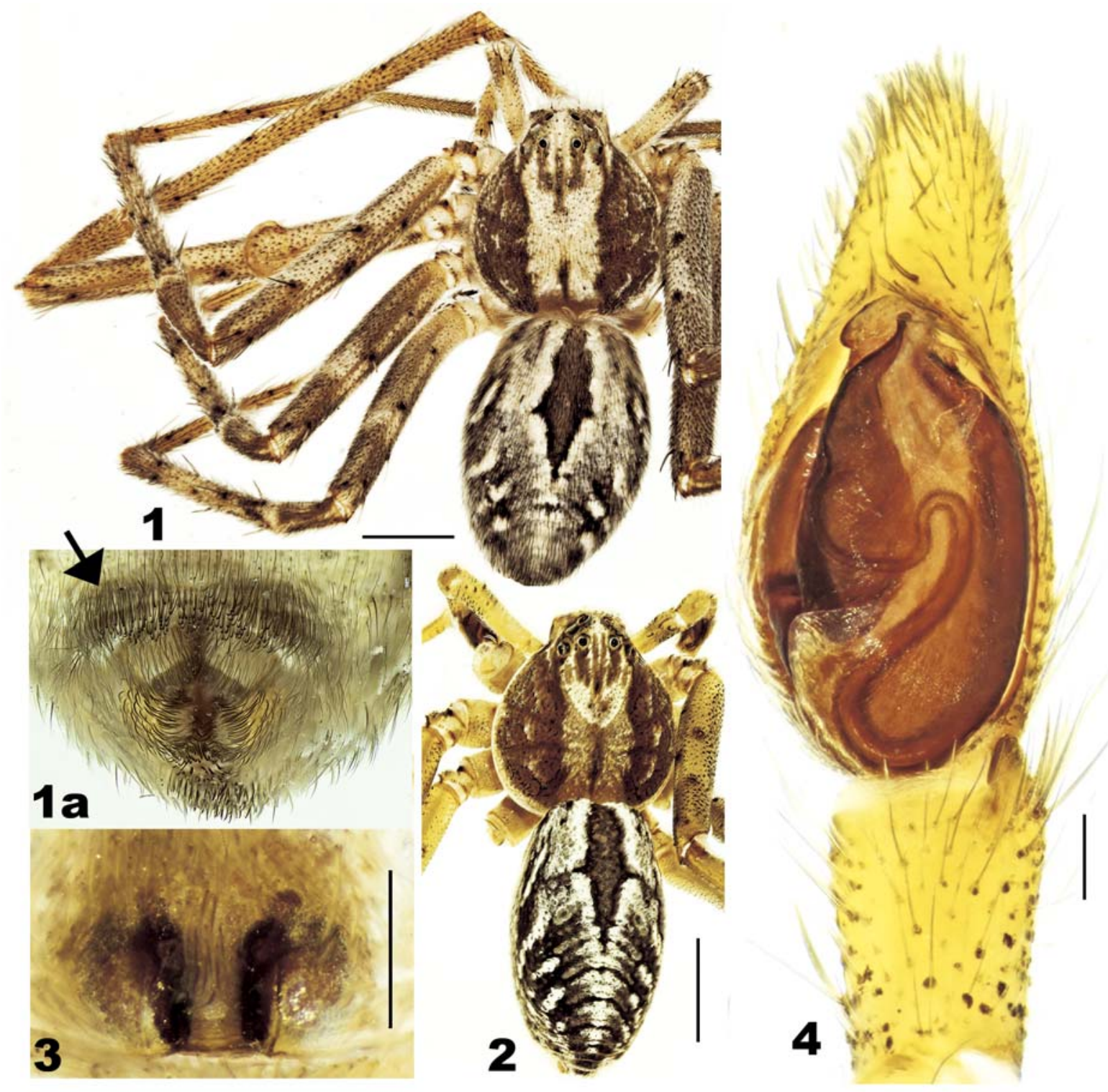

Figs 1-4. Philodromus timidus Szita et Logunov, 2008: 1 - female, dorsal view; 1a - brush of bristles near the spinnerets, ventral view; 2 - male, dorsal view; 3 - epigyne, ventral view; 4 - male palp, ventral view. Scale bars: $1-2-1 \mathrm{~mm}, 1 \mathrm{a}-$ no scale bar, 3 $0.2 \mathrm{~mm}, 4-0.1 \mathrm{~mm}$.

Pис. 1-4. Philodromus timidus Szita et Logunov, 2008: 1 - самка, сверху; 1a - ряд щетинок перед паутинными бородавками, вид снизу; 2 - самец, сверху; 3 - эпигина, снизу; 4 - пальпа самца, снизу. Масштаб: $1-2-1$ мм, 1 а - нет масштаба, $3-0,2$ мм, $4-0,1$ мм.

Szita \& Logunov [2008]. All measurements are given in millimetres.

The studied material is kept in the Museo Civico di Storia Naturale of Verona, Italy (MSNV). Additional material of Thanatus fornicatus is deposited in the Zoology Department of the Perm State University, Perm, Russia (PSU; the curator: S.L. Esyunin) and in the Siberian Zoological Museum, Novosibirsk, Russia (SZMN; the curator: A.N. Azarkina).

\section{Survey of species}

Family Philodromidae

Philodromus rufus Walckenaer, 1826

MATERIAL. PAKISTAN: 1 (MSNV), Northern Areas, Shalabat, $1700 \mathrm{~m}$, 15.VII.1976, G. Osella.

COMMENTS. This is a circum-Holarctic temperate species [Marusik et al., 2000], but records are rare and its taxonomy remains obscure; the records from 

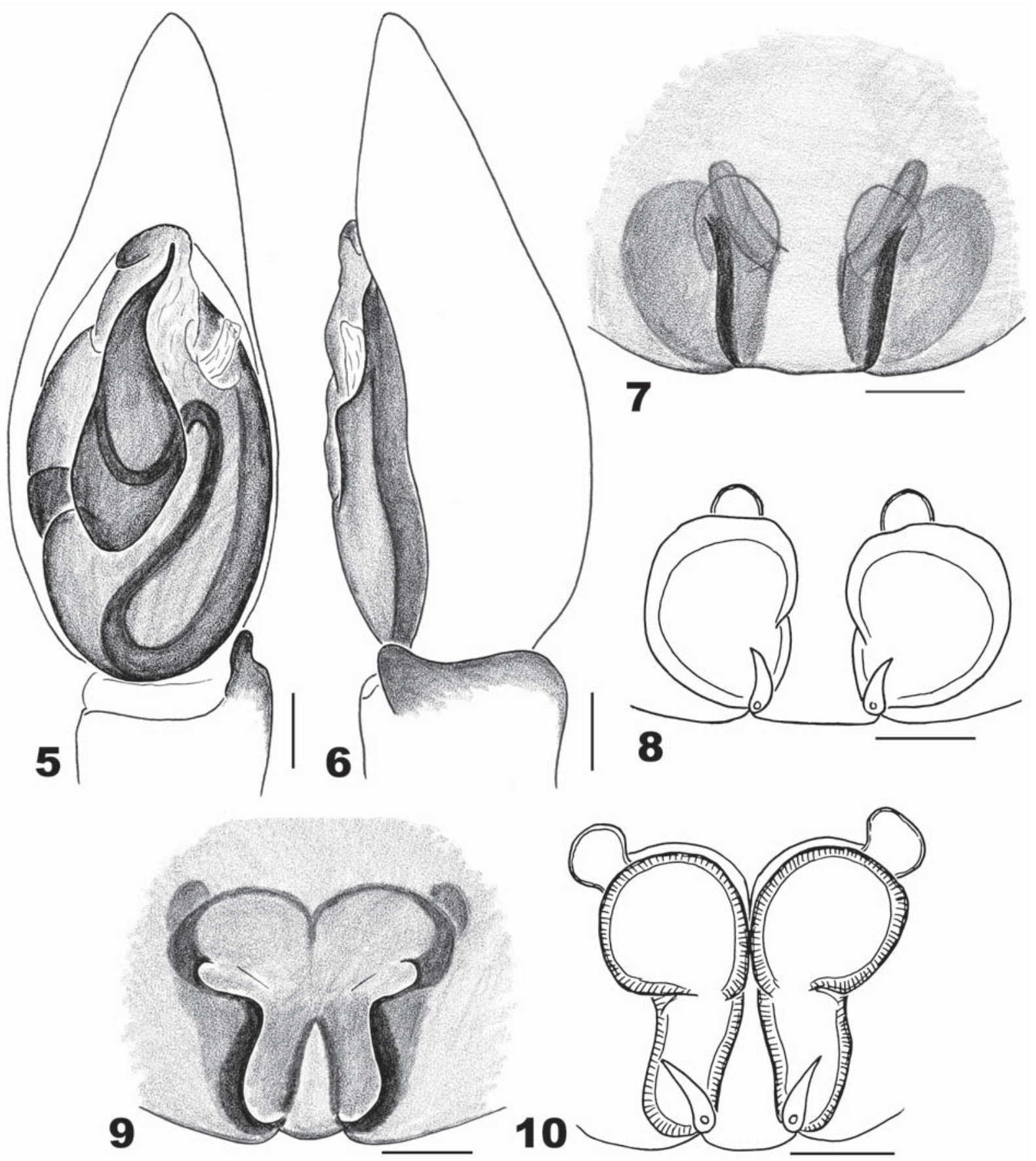

Figs 5-10. Copulatory organs of Philodromus timidus Szita et Logunov, 2008 (5-8) and Thanatus fornicatus Simon, 1897 (9-10): 5 - male palp, ventral view; 6 ditto, prolateral view; 7, 9 - epigyne, ventral view; 8, 10 - spermathecae, dorsal view. Scale bars: $0.1 \mathrm{~mm}$. Рис. 5-10. Копулятивные органы Philodromus timidus Szita et Logunov, 2008 (5-8) и Thanatus fornicatus Simon, 1897 (9-10): 5 - пальпа самца, снизу; 6 - тоже, пролатерально; 7, 9 - эпигина, снизу; 8, 10 - сперматека, сверху. Масштаб: 0,1 мм.

Karakoram lie in the southern limits of the known species range in the Palaearctic Region.

Philodromus timidus Szita et Logunov, 2008 Figs 1-8.

MATERIAL. PAKISTAN: $1 \sigma^{\gamma}$ (MSNV), Northern Areas, Gilgit Distr., Passu Glacier, 28.X.2008, L. Latella; 1 \% (MSNV),
Northern Areas, Gilgit Distr., Bagrot Valley, $5 \mathrm{~m}$ from Hinarchi Glacier, trap.1, 25.X-2.XI.2008, L. Latella \& R. Ahmed; 1 9 (MSNV), Northern Areas, Gilgit Distr., Bagrot Valley, 24.X.2008, L. Latella \& R. Ahmed; 1 ㅇ (MSNV), Northern Areas, Gilgit Distr., Bagrot Valley, $250 \mathrm{~m}$ from Hinarchi Glacier, 25.X.2008, L. Latella.

DIAGNOSIS. By the conformation of the copulatory organs, $P$. timidus is most similar to $P$. xinjiangen- 


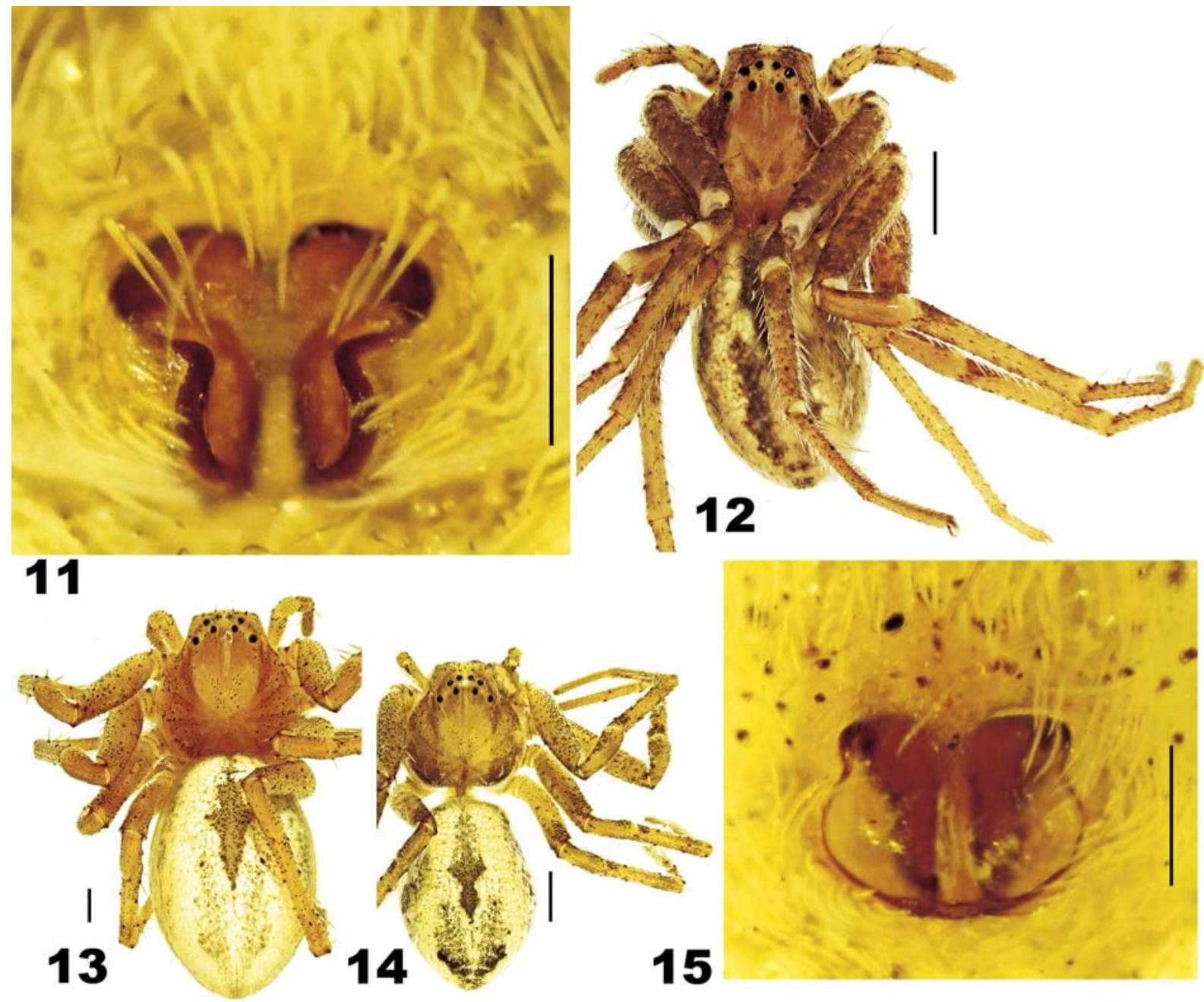

Figs 11-15. Thanatus fornicatus Simon, 1897 (11-12) and Thanatus vulgaris Simon, 1870 (13-15): 11,15 — epigyne, ventral view; 12-13 - females, dorsal view; $14-$ male, dorsal view. Scale bars: $11,15-0.2 \mathrm{~mm}, 12-13-1 \mathrm{~mm}, 14-0.5 \mathrm{~mm}$.

Рис. 11-15. Thanatus fornicatus Simon, 1897 (11-12) и Thanatus vulgaris Simon, 1870 (13-15): 11,15 — эпигина, снизу; 1213 - самка, сверху; 14 - самец, сверху. Масштаб: $11,15-0,2$ мм, 12-13-1 мм, $14-0,5$ мм.

sis Tang et Song, 1987, a widespread Central Asian species [see Szita \& Logunov, 2008: figs 45-46], but the female can be easily distinguished from it by the different shape of the medial plate of the epigyne (Figs 3,7 ) and by the more rounded spermathecae (Fig. 8). The male of $P$. timidus differs in having the flat, elongated embolus bent at its tip (Figs 4-6).

COMMENTS. An interesting morphological character of $P$. timidus omitted in its original description is a dense transverse brush of brown bristles in front of the spinnerets (Fig. 1a). The only other Philodromus species reported so far as having a similar brush of bristles is $P$. rikhteri Logunov et Huseynov, 2008 from Armenia [see Logunov \& Huseynov, 2008: figs 17-18].

DISTRIBUTION. A few records from south Kazakhstan and Pakistan [Szita \& Logunov, 2008; present data].
DESCRIPTION. MALE, see Szita \& Logunov [2008]; palpal structure as in Figs 2, 4-6.

FEMALE (from Bagrot Valley). Measurements. Carapace 2.40 long, 2.35 wide. Ocular area: MOAWA 0.40, MOA-WP 0.47, MOA-L 0.43. Eyes and interdistances: AME 0.13, ALE 0.10, PME 0.09, PLE 0.10, AME-AME 0.19, AME-ALE 0.29, PME-PME 0.31, PME-PLE 0.20. Abdomen 3.80 long, 2.50 wide. Chelicera length 0.80 . Clypeus height 0.51 . Length of leg segments: I $4.10+1.45+3.60+3.10+1.65$ (13.90); leg II $5.60+1.60+4.70+3.90+2.05(17.85)$; III $3.80+1.30+3.20+2.65+1.40(12.35)$; IV $4.30+$ $1.30+3.75+3.15+1.50(14.00)$. Leg spination of leg I: Fm d 1-1-3, pr and rt 1-1; Tb d 0-0-1, pr and rt 1-1-1, v 2-2-2-2; Mt d 2ap, pr and rt 1-1-0, v 2-2-0. Coloration. Carapace yellow, with two wide longitudinal light brown bands (Fig. 1). Clypeus yellow. Sternum yellow, maxillae and labium yellow, with small brownish speck- 


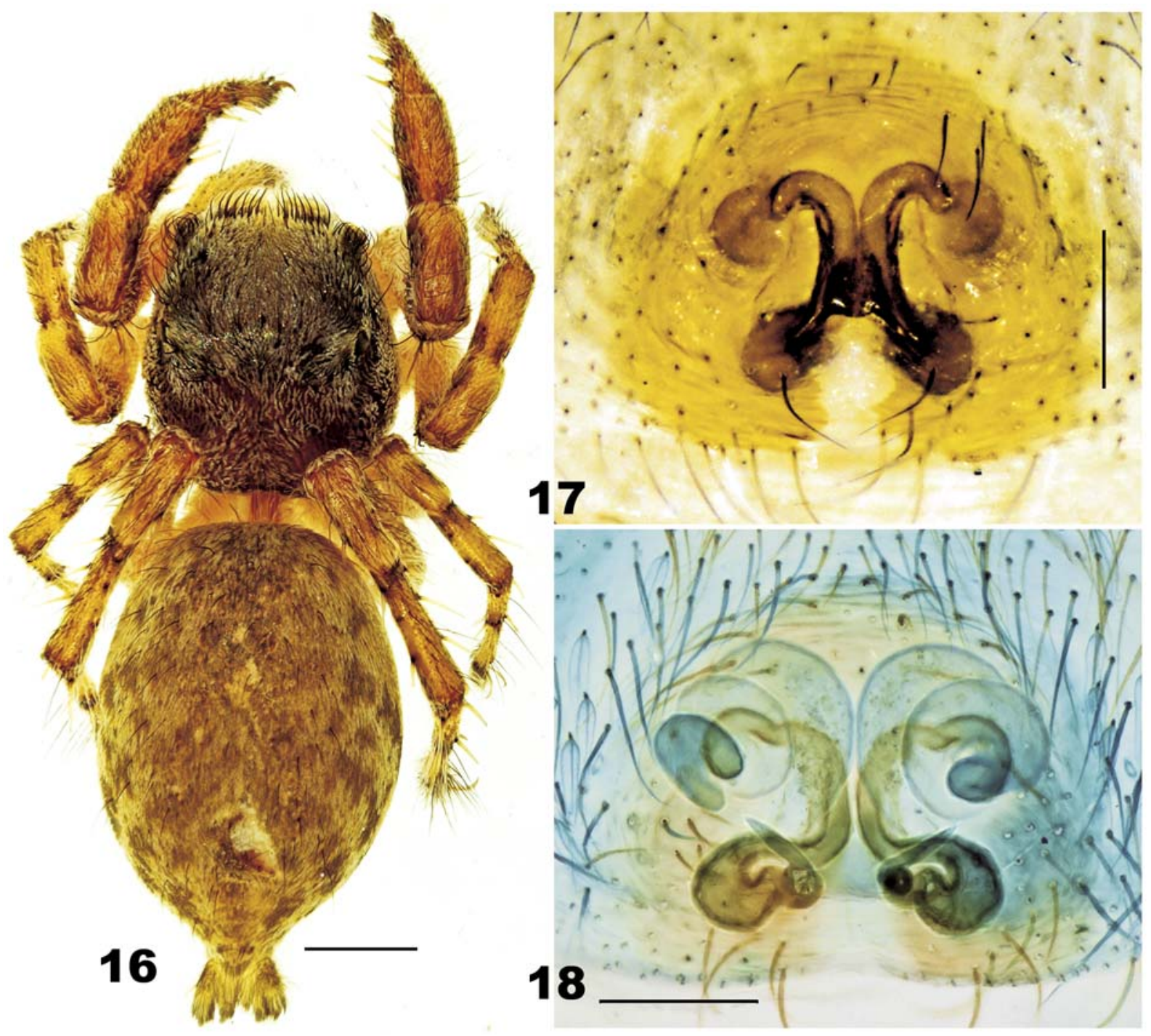

Figs 16-18. Yllenus auspex (O. Pickard-Cambridge, 1885): 16 - female, dorsal view; 17 - epigyne, ventral view; 18 spermathecae, dorsal view. Scale bars: $16=1 \mathrm{~mm}, 17-18=0.2 \mathrm{~mm}$.

Рис. 16-18. Yllenus auspex (O. Pickard-Cambridge, 1885): 16 - самка, сверху; 17 - эпигина, снизу; 18 - сперматека, сверху. Масштаб: $16=1$ мм, $17-18=0,2$ мм.

les. Abdomen: dorsum yellow, with dark grey cardiac mark and grey transverse lines running to abdominal sides (Fig. 1); venter light yellow, with brownish speckles and three longitudinal lines between epigastric furrow and spinnerets. There is a dense transverse brush of brown bristles in front of spinnerets (arrowed in Fig. 1a). Book-lung covers and spinnerets yellow. All legs and palps yellow, with numerous small brownish speckles. Epigyne and spermathecae as in Figs 3, 7-8.

\section{Thanatus fornicatus Simon, 1897}

Figs 9-12.

MATERIAL. PAKISTAN: 1 ( $($ MSNV), Northern Areas, Skardu Distr., 2300 m, 1.VII.1976, G. Osella.

ADDITIONAL MATERIAL. KAZAKHSTAN: 1 (PSU), West Kazakhstan, Baiganinski Distr., Miyakhy $\left(47^{\circ} 18^{\prime} \mathrm{N}, 55^{\circ} 31^{\prime} \mathrm{E}\right)$, sands,
30.I.2009, A.A. Ivanov. - UZBEKISTAN: 6 오 (SZMN), Bukhara Region, Kyzyk-Kum desert, nr. Gazli (c. $40^{\circ} 8^{\prime} \mathrm{N}, 63^{\circ} 27^{\prime} \mathrm{E}$ ), 21.05.1994, S.V. Ovchinnikov.

COMMENTS. To date, this species has been recorded from southern Israel, Sinai and Pakistan only [Levy, 1977, 1991]. The discovery in Karakoram is the second record of this species from Pakistan after its original description from Karachi [Simon, 1897]. These are the first species records from Uzbekistan and Kazakhstan, with its record in Kazakhstan lying in the northernmost limits of the species range.

DESCRIPTION. MALE, see Levy [1991].

FEMALE. Measurements. Carapace 2.25 long, 2.10 wide. Ocular area: MOA-WA 0.32, MOA-WP 0.46, MOA-L 0.43. Eyes and interdistances: AME 0.10, ALE 0.13, PME 0.11, PLE 0.11, AME-AME 0.14, AME-ALE 0.09, PME-PME 0.26, PME-PLE 0.30. 


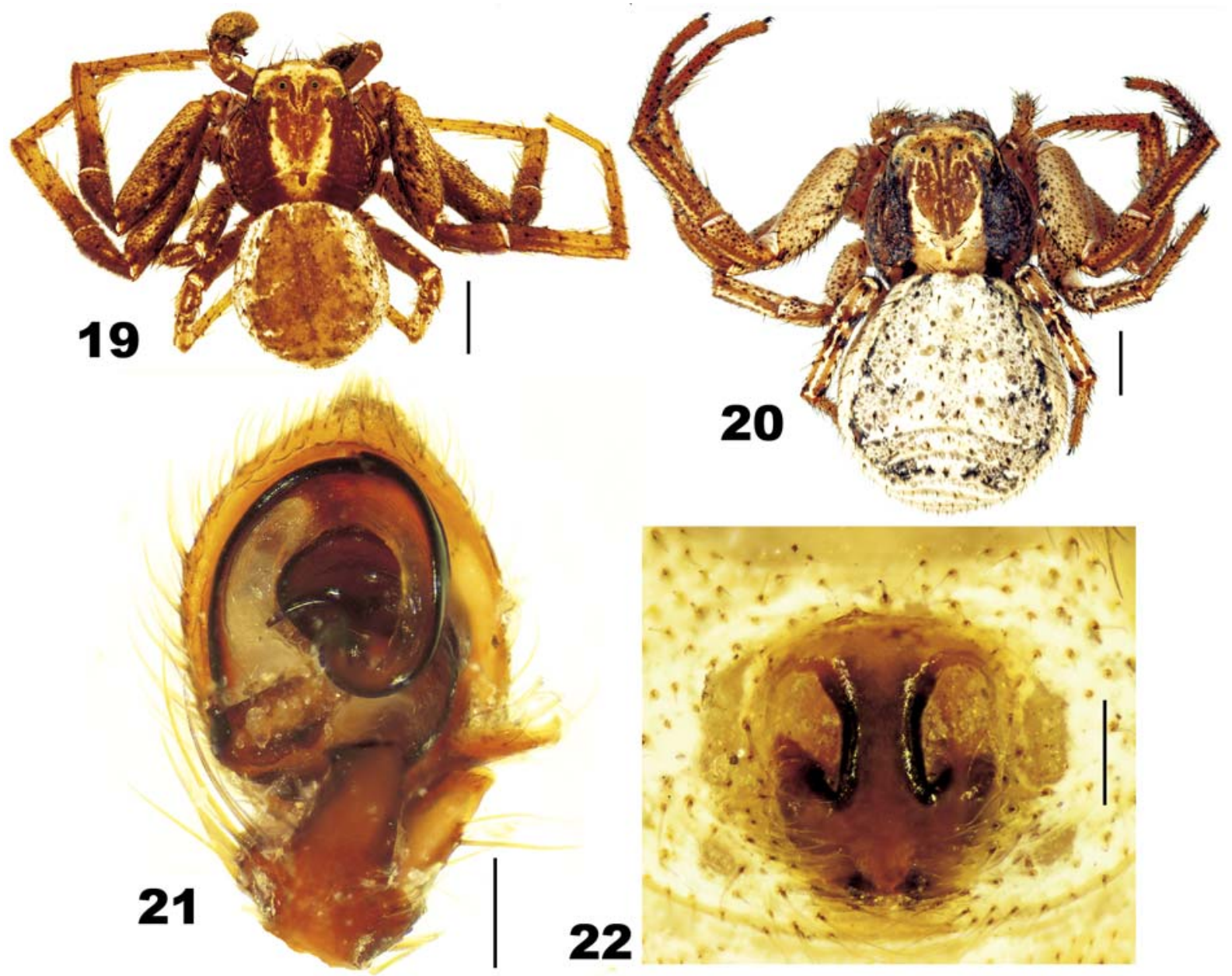

Figs 19-22. Xysticus preudocristatus Azarkina et Logunov, 2001: 19 - male, dorsal view; 20 - female, dorsal view; 21 - male palp, ventral view; $22-$ epigyne, ventral view. Scale bars: $19-20=1 \mathrm{~mm}, 21-22=0,2 \mathrm{~mm}$.

Pис. 19-22. Xysticus preudocristatus Azarkina et Logunov, 2001: 19 - самец, сверху; 20 - самка, сверху; 21 - пальпа самца, снизу; 22 - эпигина, снизу. Масштаб: 19-20=1 мм, 21-22 = 0,2 мм.

Abdomen 3.15 long, 2.00 wide. Chelicera length 0.93 . Clypeus height 0.50 . Length of leg segments: I $2.35+$ $1.00+1.95+1.60+1.05(7.95) ;$ leg II $2.80+1.15+$ $2.20+1.60+1.05(8.80) ;$ III $2.50+1.00+1.85+1.65$ $+0.90(7.90) ;$ IV $2.00+0.75+1.45+1.35+0.85$ (6.40). Leg spination of leg I: Fm d and pr 0-1-1; Tb v 2-2-0; Mt v 2-2-0. Coloration, typical for Thanatus species. Carapace yellow, with two wide marginal brown bands (Fig. 12). Clypeus yellow brownish. Sternum yellow, with brownish speckles and densely covered with white erected hairs. Maxillae and labium yellowbrown. Chelicerae yellow brownish. Abdomen light yellow, with brownish cardiac mark and V-shaped brownish figure at the rear half of dorsum (Fig. 12). Book-lung covers and spinnerets yellow. All legs: femora and patellae brownish, the remaining segments light yellow. Palps yellow, but their femora, patellae and tibiae ventrally brownish. Epigyne and spermathecae as in Figs 9-11.
Thanatus vulgaris Simon, 1870

Figs 13-15.

MATERIAL. PAKISTAN: 1 (MSNV), Northern Areas, Skardu Distr., 2300 m, 1.VII.1976, G. Osella; 19 subad. (MSNV), Northern Areas, Skardu Distr., Satpara Lake, 2700 m, 1.VII.1976, G. Osella; 1 (MSNV), Northern Areas, Ghangche Distr., Khaplu, Sciaiak channel, $2400 \mathrm{~m}, 10$.VII.1976, G. Osella.

COMMENTS. This is a common Holarctic polyzonal species [Logunov, 1996]; the records from Karakoram lie in southern limits of the known species range in the Palaearctic Region.

\section{Family Salticidae}

Pellenes epularis (O. Pickard-Cambridge, 1872)

MATERIAL. PAKISTAN: 1 (MSNV), Northern Areas, Shalabat, $1700 \mathrm{~m}, 15$.VII.1976 G. Osella. 
COMMENTS. This is a common Mediterranean Central Asian species, known from Madeira and the Levant, throughout Minor Asia and the Near East to Central Asia (Tajikistan and Pakistan) [see Logunov et al., 1999; present data]; the records from Karakoram lie in the easternmost limit of the species range.

\section{Sitticus avocator (O. Pickard-Cambridge, 1885)}

MATERIAL. PAKISTAN: $1+$ (MSNV), Northern Areas, Gilgit Distr., Bagrot Valley, 18.VI.2008, L. Latella \& R. Ahmed.

COMMENTS. This is a common Central Asian species, known from the south-east mountain regions of Central Asia (south Kazakhstan and Kyrgyzstan), eastward to north-west China (Xinjiang) [see Logunov $\&$ Marusik, 2000]; the records from Karakoram lie in the south-westernmost limit of the species range.

\section{Yllenus auspex (O. Pickard-Cambridge, 1885)} Figs 16-18.

MATERIAL. PAKISTAN: 2 오 (MSNV), Northern Areas, Skardu Distr., 2300 m, 1.VII.1976, G. Osella; 1 ( (MSNV), Northern Areas, Ghangche Distr., Khaplu, Sciaiak channel, $2400 \mathrm{~m}$ 10.VII.1976, G. Osella.

COMMENTS. This is a rare Central Asian species, known from east Mongolia, west China (Xinjiang and Gansu) [see Logunov \& Marusik, 2003]; the records from Karakoram lie in the south-westernmost limit of the species range. The female of $Y$. auspex from Mongolia illustrated earlier by Logunov \& Marusik [2003: figs 422-424] is not very typical of the species. The one studied and illustrated in the present work (Figs 17-18) is virtually identical with the $O$ paralectotype from Yarkand [see Prószyński \& Żochowska, 1981: figs 27-30].

\section{Family Thomisidae}

Xysticus preudocristatus Azarkina et Logunov, 2001 Figs 19-22.

MATERIAL. PAKISTAN: 1 ( $($ MSNV), Northern Areas, Skardu Distr., Shigar-tang, 2500-3300 m 12.-15.VII.1976, G. Osella $10^{7}$ (MSNV), Northern Areas, Skardu Distr., Pakova, $2300 \mathrm{~m}$ 17.VII.1976, G. Osella; 1 ( 9 (MSN), Northern Areas, Skardu District, Katzarah, 2200 m, 23.VII.1976, G. Osella; 1 क (MSNV), Northern Areas, Gilgit Distr., Bagrot Valley, 17.VI.2008, L. Latella; $10^{7}$ (MSNV), Northern Areas, Skardu Distr., Doesai Plateau, 27.VI.2008, 3900-4200 m, L. Latella.

COMMENTS. This is a common Central Asian mountain species, known from Nepal-Himalayas and Tibet, northwards to southern regions of west Siberia and central Mongolia [see Azarkina \& Logunov, 2001]; the records from Karakoram lie within the known range of the species.

ACKNOWLEDGMENTS. We are particularly thankful to Seppo Koponen who allowed us to use the microscopic and digital equipment available in the Zoological Museum of Turku University (Finland), Leonardo Latella who gave us the opportunity to study material from the collection of the Museo Civico di Storia Naturale of Verona (Italy), and Sergei L. Esyunin who allowed us to study some Philodromidae material from the PSU (Russia). David Penney (Manchester, UK) is thanked for his kind linguistic help.

\section{References}

Azarkina G.N., Logunov D.V. 2001. Separation and distribution of Xysticus cristatus (Clerck, 1758) and X. audax (Schrank, 1803) in eastern Eurasia, with description of a new species from the mountains of Central Asia (Aranei: Thomisidae) // Arthropoda Selecta. Vol.9 (for 2000). No.2. P.133-150.

Butt A., Beg M.A. 2000. Some new species of Marpissa (Salticidae) spiders from Pakistan // Pakistan J. Zool. Vol.32. No.1. P.75-79.

Caporiacco L. di. 1934. Aracnidi dell'Himalaia e del Karakoram, raccolti dalla Missione italiana al Karakoram (1929-VII) // Mem. della Soc. Entomol. Italiana. Vol.13. P.113-263.

Ghafoor A., Alvi Z.H. 2008. Biodiversity of araneid fauna from the Trifolium alexandrinum fields at Gutwala, district Faisarabad, Pakistan // Biologia (Pakistan). Vol.54. No.1. P.43-48.

Kok O.B., Haddad C.R., van Niekerk D.J., Butler H.J.B., Nawaz M.A. 2005. Invertebrates as a potential food source of brown bears on the Deosai Plateau, northern Pakistan // Pakistan J. Biol. Sci. Vol.8. No.1. P.13-19.

Kok O.B., Lotz L.N., Haddad C.R. 2004. Diversity and ecology of spiders (Arachnida: Araneae) of the Deosai Plateau, northern Pakistan // Pakistan J. Biol. Sci. Vol.7. No.10. P.1689-1694.

Levy G. 1977. The philodromid spiders of Israel (Araneae: Philodromidae) // Israel J. Zool. Vol.26. Vol.193-229.

Levy G. 1991. On some new and uncommon spiders from Israel (Araneae) // Bull. Br. arachnol. Soc. Vol.8. No.7. P.227-232.

Logunov D.V. 1996. A critical review of the spider genera Apollophanes O. P.-Cambridge, 1898 and Thanatus C.L. Koch, 1837 in North Asia (Araneae, Philodromidae) // Rev. arachnol. Vol.11. No.13. P.133-202.

Logunov D.V., Huseynov E.F. 2008. A faunistic review of the spider family Philodromidae (Aranei) of Azerbaijan // Arthropoda Selecta. Vol.17. No.1/2. P.117-131.

Logunov D.V., Marusik Yu.M. 2000. Catalogue of the jumping spiders of northern Asia (Arachnida, Araneae, Salticidae). Moscow: KMK Scientific Press. 299 pp.

Logunov D.V., Marusik Yu.M. 2003. A revision of the genus Yllenus Simon, 1868 (Arachnida, Araneae, Salticidae). Moscow: KMK Scientific Press. 167 pp.

Logunov D.V., Marusik Yu.M., Rakov Yu.M. 1999. A review of the genus Pellenes in the fauna of Central Asia and the Caucasus // J. Nat. Hist. Vol.33. No.1. P.89-148.

Marusik Yu.M., Ballarin F. 2011a. A new species of Draconarius (Araneae, Amaurobioidea, Coelotinae) from northern Pakistan // Zootaxa. N.2739. P.27-32.

Marusik Yu.M., Ballarin F. 2011b. Redescription of the Himalaian Pardosa flavisterna Caporiacco, 1935 (Aranei: Lycosidae) with notes of the Pardosa nebulosa species-group // Proc. Zool Inst. RAS. Vol.315. No.1. P.63-69.

Marusik Yu.M., Logunov D.V., Koponen S. 2000. Spiders of Tuva, South Siberia. Magadan: IBPS DVO RAS. 252 pp.

Mushtaq S., Beg M.A., Waris M. 1995. A new species and a new record from the genus Phlegra Simon (Araneae: Salticidae) from Pakistan // Pakistan J. Zool. Vol.27. No.3. P.241-244.

Ovtchinnikov S.V. 2006. New genus and species of spiders of the subfamily Zodariinae (Araneae, Zodariidae) from Pakistan // Vestn. Zool. Vol.40. P.77-79.

Ovtchinnikov S.V., Ahmad B., Inayatullah M. 2008. Description of a new spider species of the genus Gnaphosa (Araneae, Gnaphosidae) from Pakistan // Vestn. zool. Vol. 42. No.1. P.81-83.

Ovtchinnikov S.V., Inayatullah M. 2005. Two new spider species of the genus Draconarius (Araneae, Amaurobiidae, Coelotinae) from Pakistan // Vestn. Zool. Vol.39. No.1. P.85-88. 
Prószyński J., Zochowska K. 1981. Redescriptions of the O. Pickard-Cambridge Salticidae (Araneae) types from Yarkand, China // Polskie Pismo ent. Vol.51. P.13-35.

Simon E. 1897. Arachides recueillis par M. M. Maindron à Kurrachee et à Matheran (près Bombay) en 1896 // Bull. Mus. hist. nat. Paris, 1897. P.289-297.
Szita E., Logunov D.V. 2008. A review of the histrio group of the spider genus Philodromus Walckenaer, 1826 (Philodromidae, Araneae) of the eastern Palaearctic Region // Acta Zool. Acad. Sci. Hung. Vol.54. No.1. P.23-73.

Responsible editor K.G. Mikhailov 